\title{
Algerian Carob Tree Products: A Comprehensive Valorization Analysis and Future Prospects
}

\author{
Rosa Mahtout ${ }^{1,2}$, Víctor Manuel Ortiz-Martínez ${ }^{2}$, María José Salar-García ${ }^{2}$, Isabel Gracia ${ }^{2}$, \\ Francisco José Hernández-Fernández ${ }^{2, *}$, Antonia Pérez de los Ríos ${ }^{3}$, Farid Zaidia ${ }^{1}$, \\ Sergio Sanchez-Segado ${ }^{2}$ and Luis Javier Lozano-Blanco ${ }^{2}$ \\ 1 Department of Food Science, Faculty of Natural Sciences and Life, Abderrahmane Mira University, \\ Bejaia 06000, Algeria; rosamahtout@yahoo.fr (R.M.); idiazdiraf@yahoo.fr (F.Z.) \\ 2 Department of Chemical and Environmental Engineering, Technical University of Cartagena, Campus \\ Muralla del Mar C/Doctor Fleming s/n, Cartagena, 30202 Murcia, Spain; victor.ortiz@upct.es (V.M.O.-M.); \\ mariajose.salar@upct.es (M.J.S.-G.); isabelgb85@gmail.com (I.G.); S.SanchezSegado@leeds.ac.uk (S.S.-S.); \\ luisja.lozano@upct.es (L.J.L.-B.) \\ 3 Department of Chemical Engineering, Faculty of Chemistry, University of Murcia, 30071 Murcia, Spain; \\ aprios@um.es \\ * Correspondence: fj.herfer@upct.es
}

Received: 30 October 2017; Accepted: 29 December 2017; Published: 1 January 2018

\begin{abstract}
This research presents a thorough analysis of the nutrients and anti-nutrients contained in different products from Algerian carob tree, Ceratonia siliqua L. (pod, pulp, seeds and leaves). Other parameters such as moisture, ash content and calorific value were also determined. The main purpose was to characterize these products derived from carob tree and analyze their possible valorization in several fields such as chemical, energy or medical industries. The results show that these products contain low amount of crude lipids (2.4-4.5\%), moderate amounts of protein $(4-7.4 \%)$ and high levels of total sugar (up to $66.6 \%$ ). The compositional analysis reveals high nutritional values but, at the same time, it is also worth underscoring their high content in anti-nutrients: (i) trypsin inhibitor $\left(6.4-7.3 \mathrm{mg} \cdot \mathrm{g}^{-1}\right)$; and (ii) phytic acid $\left(0.6-0.94 \mathrm{mg} \cdot \mathrm{g}^{-1}\right)$. This work quantifies these two secondary metabolites in carob tree products for the first time. Finally, based on the results obtained, a process scheme is proposed for the complete use of carob tree products, including the use of anti-nutrients (trypsin inhibitors and phytic acid) for bio-medical applications since many research studies support that these compounds have great potential in this field.
\end{abstract}

Keywords: carob tree; valorization; anti-nutrients; sugars; proteins; lipids; calorific value

\section{Highlights}

- Nutrient and anti-nutrient characterization of Algerian carob tree fruits.

- Low amount of crude lipids and moderate content of protein in carob tree products.

- High content of sugars, especially in seeds and pod.

- High amount of anti-nutrients such us trypsin inhibitor and phytic acid.

- High content of secondary metabolites for bio-medical applications.

\section{Introduction}

The carob tree (Ceratonia siliqua L.) is an evergreen shrub or tree native to the Mediterranean region, which is cultivated for animal and human consumption. In recent years, its commercial value has increased due to the use of its fruits as raw material in food, pharmaceutical, cosmetic and biofuel industries $[1,2]$. The environmental role of carob pod tree is also attracting attention since it can be 
used in reforestation actions to revalorize marginal lands, as a substitute for drought sensitive species and as carbon dioxide sinks to mitigate global warming effects [3,4].

Carob tree offers the advantage of growing in poor and unfertile soils in the Mediterranean region and in the other parts of the world and do not require much water for irrigation. Therefore, carob tree plantations could help to compensate the expanding land desertification in these areas [5]. The annual production of carob pods ranges from 374,800 to 441,000 tons with an average productivity of $2000-3500 \mathrm{Kg} / \mathrm{ha}$, depending on the growing region and farming practices, being Spain, Italy and Portugal the main producers $[6,7]$.

The two main carob pod constituents are pod skins ( $90 \%$ by weight) and seeds ( $10 \%$ by weight). Carob pod has a high amount of total sugar content (48-56\%), which mainly consists of sucrose, glucose, fructose and maltose in variable proportions and approximately $18 \%$ of cellulose and hemicellulose. Carob seeds are extremely hard and contain $30-40 \%$ by weight of galactomannan, a polysaccharide molecule composed by mannose and galactose sugar units, also known as carob bean gum, which is mostly used in the food industry to obtain a high quality, nutritious and superb tasting fodder for horses, cattle and goats [8].

The development of an environmental friendly chemical industry has promoted that both industry and research focus their effort on the exploitation of biomass sources, which opens a new way for the revalorization of carob pod among other biomass sources $[9,10]$. Carob tree is a sugar-rich biomass which may theoretically be ideal for biofuel production carob [11]. Several studies have delved into the production of ethanol from carob pod, showing its technical and economical competitiveness compared with other traditional crops [12-14]. Other works have also assessed the use of this dryland forest crop for the efficient production of biohydrogen [15]. Thus, carob tree could represent an alternative and renewable source of bioenergy

On the other hand, carob tree products include anti-nutrients such as trypsin inhibitors and phytic acid with promising applications in assorted fields. To this regard, phytic acid is well known as antioxidant that can be used both for biomedicine purposes and as an important food preservative [1].

The aim of this work is to characterize Algerian Ceratonia siliqua L. products, such as pod, pulp, seed and leaves, specifically in terms of nutrient and anti-nutrient content, exploring its potential for food-related process applications. This information provides a good basis for the future study of the relationship between anti-nutritional factors and the protein digestibility of carob tree products. Other important parameters such as moisture, ash and caloric values were also analyzed. In addition, an integral approach for the valorization of Algerian carob tree products is presented in this work based on the thorough analysis performed, including processes for the separation of the respective compounds.

\section{Materials and Methods}

\subsection{Samples}

Samples of carob (pod and leaves) were collected from the region of Tazmalt in northern Algeria, where Carob tree (Ceratonia siliqua L.) naturally grows. The samples were harvested during September 2011. The seeds were removed from $1 \mathrm{~kg}$ of carob pod to obtain pulp sample, and another $\mathrm{kg}$ of carob pod was milled with the seeds to obtain pod sample. All pod, pulp, seed and leave samples were ground with a crusher $\left(\mathrm{IKA}^{\circledR}\right.$, A 11 basic, Staufen, Germany) and passed through a 500- $\mu \mathrm{m}$ sieve before analyses.

\subsection{Fractionation of Proteins}

The fractionation of protein was performed according to the Osborne method [16] with some modifications. Defatted wheat flour $(0.5 \mathrm{~g})$ was sequentially extracted by this method. Albumin-globulin extraction was done by using a $0.5 \mathrm{M} \mathrm{NaCl}(10 \mathrm{~mL})$ aqueous solution for $30 \mathrm{~min}$ at $4{ }^{\circ} \mathrm{C}$, this step being repeated three times, and then by centrifugation at 20,000 $\times g$ for $15 \mathrm{~min}$. All supernatants (albumin + globulin extracts) were transferred and diluted with $0.5 \mathrm{M} \mathrm{NaCl}$ in a 
volumetric flask up to $50 \mathrm{~mL}$. The solid waste was extracted with a $70 \% v / v(10 \mathrm{~mL})$ ethanol solution in the same conditions mentioned above for recovering gliadin. The total soluble glutenin was recovered by solvent extraction using a $50 \% v / v$ solution of 1-propanol and $1 \% v / v$ dithiothreitol from the solid residue after gliadin extraction. The content of insoluble glutenin was calculated as the difference between content of total protein and sum of albumin + globulin, gliadin and soluble glutenin. Protein content was calculated, in each fraction, from the nitrogen content determined by an elemental nitrogen analyzer Model TOC-V CSH SHIMADZU. The results are given as percentage of dry weight.

\subsection{In Vitro Protein Digestibility}

Defatted samples $(0.3 \mathrm{~g})$ were incubated $\left(37^{\circ} \mathrm{C}, 3 \mathrm{~h}\right)$ with pepsin in $0.1 \mathrm{~N} \mathrm{HCl}$ followed by inactivation with $1 \mathrm{~N} \mathrm{NaOH}$. Incubation was continued $\left(24 \mathrm{~h}, 37^{\circ} \mathrm{C}\right)$ with trypsin and $\alpha$-chymotrypsin in potassium phosphate buffer, $\mathrm{pH}$ 8.0, followed by inactivation with trichloroacetic acid (TCA). Zero-time control was maintained by inactivating the enzyme before addition of substrate. The inactivated reaction mixtures were centrifuged and the supernatant was collected. The residue was washed with $10 \% v / v$ TCA solution and centrifuged. The combined supernatant was extracted with diethyl ether twice and the ether layer was discarded by aspiration. The aqueous layer was then heated for $15 \mathrm{~min}$ with a boiling water bath to remove traces of ether. Nitrogen $(\mathrm{N})$ was determined to calculate protein in the digest using an elemental nitrogen analyzer Model TOC-V CSH SHIMADZU and the in vitro Protein Digestibility (IVPD) was calculated as follows [17]:

$$
\operatorname{IVPD}(\%)=(\text { Protein in digest }) /(\text { Protein in defatted flour }) \times 100
$$

\subsection{Trypsin Inhibitory Factor}

One gram of sample was digested with sodium hydroxide $0.1 \mathrm{M}$ at room temperature and $\mathrm{pH}$ between 9.5 and 9.8. This suspension was diluted to the point that the inhibition of trypsin was 40 to $60 \%$. One milliliter of diluted sample was mixed with equal amount of distilled water and $2 \mathrm{~mL}$ of trypsin solution $(20 \mathrm{mg} / \mathrm{L}$ of $0.01 \mathrm{MHCl})$, and the mixture was incubated at $37^{\circ} \mathrm{C}$ for $10 \mathrm{~min}$. After incubation, $5 \mathrm{~mL}$ of benzyl-DL-arginine-para-nitroanilide (BAPNA) solution were added and mixed at $37^{\circ} \mathrm{C}$ for 10 minutes. The reaction was stopped by adding $1 \mathrm{~mL}$ of $30 \% v / v$ acetic acid solution. After centrifugation, the absorbance of the solution was measured at $410 \mathrm{~nm}$ using a SHIMADZU UV-1650PC UV-VIS spectrophotometer [18]. Trypsine inhibitor activity (TIA) was calculated as:

$$
\text { TIA }=(2.632 \mathrm{D} \text { A1) } / \mathrm{S}=\text { milligrams pure trypsin } / \mathrm{g} \text { sample }(\mathrm{mg} / \mathrm{g})
$$

where $\mathrm{D}$ is the dilution factor, $\mathrm{A} 1$ is the change in absorbance (pure trypsin and sample extract) and $S$ is the sample weight $(\mathrm{g})$.

\subsection{Phytic Acid Determination}

Finely grounded sample (1.4 g) was extracted with $50 \mathrm{~mL}$ of $3 \%$ TCA solution and centrifuged at $3000 \mathrm{rpm}$ for $10 \mathrm{~min}$. Twenty milliliters of the clear solution were mixed with $4 \mathrm{~mL}$ of $\mathrm{FeCl}_{3}(5.8 \mathrm{~g}$ dissolved in $1 \mathrm{~L}$ of $3 \%$ TCA solution) and heated in a boiling water bath for $45 \mathrm{~min}$. The precipitated formed was washed three times with hot distilled water, $3 \%$ TCA solution and $0.15 \mathrm{~N} \mathrm{NaOH}$ solution, respectively, and then was dissolved in $1.3 \mathrm{~N} \mathrm{HNO}_{3}$ and diluted to $100 \mathrm{~mL}$ with $0.3 \mathrm{M} \mathrm{KSCN}$ solution. The absorbance of the sample was measured at $480 \mathrm{~nm}$ using a SHIMADZU UV-1650PC UV-VIS spectrophotometer and was compared with standards prepared using $\mathrm{Fe}\left(\mathrm{NO}_{3}\right)_{3}$ dissolved in $0.3 \mathrm{M}$ KSCN [18].

\subsection{Sugar Analysis}

The sugars were extracted with water at room temperature according to Biner et al. [19] with slight modifications. Ten grams of ground dried pods were mixed with $40 \mathrm{~mL}$ of water, homogenized 
using a macerator and centrifuged at $6000 \mathrm{rpm}$ for $30 \mathrm{~min}$ at room temperature. The supernatant was filtered with filter paper and $2.5 \mathrm{~mL}$ of filtrate was mixed with $7.5 \mathrm{~mL}$ of acetonitrile. The mixture was filtered through a 0.45 micropore membrane. Quantification and identification of the different sugars were performed by ion chromatography with PAD detector using a Metrosep Carb 1-150 column and $80 \mathrm{mM} \mathrm{NaOH}$ as mobile phase. The chromatographic system used is ion chromatography with PAD detector (Metrohm, FL, USA).

Individual sugars were quantified by comparison with external standards of pure fructose, glucose and sucrose (Sigma-Aldrich, St. Louis, MO, USA). Calibration curves were constructed for all standard sugar solutions.

\subsection{Proximate Analysis}

The contents of moisture, ash and crude lipid (Soxhlet extraction) were determined according to the AOAC (1990) procedures [20]. The total $\mathrm{N}$ and crude protein $(\mathrm{N} \times 6.25)$ content of the samples were determined by using combustion $\mathrm{N}$ analysis (AOAC, 1997, N analyzer Flash EA ${ }^{\circledR} 1122$; Thermo Scientific, West Palm Beach, FL, USA) with EDTA as standard [21].

\subsection{Calorific Values}

The calorific value was calculated according to the following expression [22]:

$$
\begin{gathered}
\text { Calorific value } \mathrm{kJ} / 100 \mathrm{~g} \text { of dry matter }=\text { [crude protein }(\%) \times 4]+[\text { crude lipid }(\%) \times 9] \\
+[\text { crude carbohydrates }(\%) \times 4]
\end{gathered}
$$

\subsection{Statistical Analyses}

All analytical measurements were done in triplicate. Values were averaged and given with standard deviation $( \pm S D)$. Data were subjected to one-way analysis of variance (ANOVA, F-test). Significance of mean differences was determined. Significance was accepted at $p \leq 0.05$. Superscripts a, $b, c, d$ throughout the text are related to statistical tests performed by ANOVA. For a given parameter, the values that not share the same letter are significantly different.

\section{Results and Discussion}

\subsection{Chemical Composition of Carob Tree Products}

Moisture, ash, total protein, fat, and carbohydrate profile of the sample are shown in Table 1. As can be seen, moisture percentage and ash content range from 8.4 to $9.5 \%$ and 2.6 to $7.3 \%$, respectively. It is worth noting that the maximum amount of ash was found in the leaves. These results are in line with previous findings on carob powder [23].

Table 1. Composition of the carob pod products in percent of dry matter. Data are presented as mean \pm standard deviation $(n=3)$. Data in the same column, marked with the same letter are not significantly different $(p>0.05)$.

\begin{tabular}{ccccccc}
\hline Sample & Moisture (\%) & Ash (\%) & $\begin{array}{c}\text { Crude } \\
\text { Protein (\%) }\end{array}$ & Crude Fat (\%) & $\begin{array}{c}\text { Total } \\
\text { Sugars (\%) }\end{array}$ & $\begin{array}{c}\text { Calorific } \\
\text { Value kJ/100 g }\end{array}$ \\
\hline Pod & $9.5 \pm 0.09^{\mathrm{a}}$ & $2.6 \pm 0.3^{\mathrm{a}}$ & $4.0 \pm 0.04^{\mathrm{b}}$ & $2.4 \pm 0.02^{\mathrm{c}}$ & $66.6 \pm 1.8^{\mathrm{a}}$ & $301.5 \pm 1.4^{\mathrm{a}}$ \\
Pulp & $8.4 \pm 0.06^{\mathrm{a}}$ & $3.0 \pm 0.03^{\mathrm{b}}$ & $3.0 \pm 0.06^{\mathrm{a}}$ & $1.5 \pm 0.04^{\mathrm{a}}$ & $65.0 \pm 3.3^{\mathrm{a}}$ & $284.6 \pm 17.4^{\mathrm{a}}$ \\
Seed & $9.4 \pm 0.02^{\mathrm{a}}$ & $4.5 \pm 0.03^{\mathrm{c}}$ & $18.6 \pm 0.3^{\mathrm{d}}$ & $2.0 \pm 0.08^{\mathrm{b}}$ & $5.2 \pm 1.0^{\mathrm{b}}$ & $113.1 \pm 5.0^{\mathrm{b}}$ \\
Leaves & $8.4 \pm 0.06^{\mathrm{a}}$ & $7.3 \pm 0.08^{\mathrm{d}}$ & $7.4 \pm 0.07^{\mathrm{c}}$ & $4.5 \pm 0.1^{\mathrm{d}}$ & $15.7 \pm 2.0^{\mathrm{c}}$ & $133.0 \pm 7.7^{\mathrm{c}}$ \\
\hline \multicolumn{6}{c}{ a,b,c,d: For a given parameter, the values that do not share the same letter are significantly different. }
\end{tabular}


The results also show that the carob pod is a low fat fruit rich in carbohydrates, which is in good agreement with the results showed in previous studies $[19,21]$. Most of the sugar amount is present in the pulp and the pod. As pod consists of pulp and seeds, the amount of sugar in the pod should be higher than in the pulp. The seed contains the maximum amount of protein and the minimum amount of sugar. The carob pod could be interesting as food because it is known that legume carbohydrates reduce cholesterol and increase blood glucose levels [22].

No significant differences $(p>0.05)$ were observed between the calorific value of carob pod and pulp [22]. The lowest calorific value was found in the seeds. Regarding the type of sugar in the carob pod (Table 2), the highest amount of sugar corresponds to sucrose. Much lower amounts of glucose and fructose were founded, and fructose was not found in the seeds analyzed. Total sugars in Tables 1 and 2 include the total amount of sucrose, glucose, fructose and remaining sugars present in the sample.

Table 2. Sugar content of the carob pod products in percent of dry matter. Data are presented as mean \pm standard deviation $(n=3)$. Data in the same column, marked with the same letter are not significantly different $(p>0.05)$ (ANOVA test).

\begin{tabular}{ccccc}
\hline Sample & Sucrose (\%) & Glucose (\%) & Fructose (\%) & Total Sugars (\%) \\
\hline Pod & $55.9 \pm 1.4^{\mathrm{d}}$ & $9.2 \pm 0.2^{\mathrm{a}}$ & $11.5 \pm 0.1^{\mathrm{c}}$ & $66.6 \pm 1.8^{\mathrm{a}}$ \\
Pulp & $50.2^{\mathrm{a}} \pm 1.6^{\mathrm{c}}$ & $11.9 \pm 0.1^{\mathrm{a}}$ & $13.1 \pm 0.3^{\mathrm{d}}$ & $65.0 \pm 3.3^{\mathrm{a}}$ \\
Seed & $7.2 \pm 1.8^{\mathrm{a}}$ & $0.4 \pm 0.1^{\mathrm{b}}$ & $0.0 \pm 00^{\mathrm{a}}$ & $7.6 \pm 1.0^{\mathrm{b}}$ \\
Leaves & $9.5 \pm 0.9^{\mathrm{b}}$ & $5.0 \pm 0.5^{\mathrm{c}}$ & $2.6 \pm 0.5^{\mathrm{b}}$ & $17.1 \pm 2.0^{\mathrm{c}}$ \\
\hline
\end{tabular}

$\mathrm{a}, \mathrm{b}, \mathrm{c}, \mathrm{d}$ : For a given parameter, the values that do not share the same letter are significantly different.

\subsection{Fractionation and In Vitro Protein Digestibility}

The total protein of carob was fractionated based on solubility of each product into albumins + globulins, gliadins, soluble and insoluble glutenins. The results obtained after the fractionation of the protein are shown in Table 3. The protein fraction with the lowest value was albumin + globulin, being gliadin and insoluble glutenin the major storage proteins.

Table 3. Fractionation of the protein in percent of dry matter. Data are presented as mean \pm standard deviation $(n=3)$. Data in the same column, marked with the same letter are not significantly different $(p>0.05)$.

\begin{tabular}{ccccc}
\hline Sample & Albumin + Globulin & Gliadin & Soluble Glutenin & Insoluble Glutenin \\
\hline Pod & $0.12 \pm 0.01^{\mathrm{c}}$ & $0.53 \pm 0.01^{\mathrm{c}}$ & $0.59 \pm 0.01^{\mathrm{c}}$ & $2.67 \pm 0.01^{\mathrm{a}}$ \\
Pulp & $0.01 \pm 0.001^{\mathrm{a}}$ & $0.048 \pm 0.001^{\mathrm{b}}$ & $0.03 \pm 0.001^{\mathrm{a}}$ & $2.61 \pm 0.05^{\mathrm{a}}$ \\
Seed & $0.03 \pm 0.001^{\mathrm{b}}$ & $0.057 \pm 0.001^{\mathrm{a}}$ & $0.032 \pm 0.001^{\mathrm{b}}$ & $18.48 \pm 0.2^{\mathrm{c}}$ \\
Leaves & $0.01 \pm 0.001^{\mathrm{a}}$ & $0.055 \pm 0.001^{\mathrm{a}}$ & $0.03 \pm 0.001^{\mathrm{a}}$ & $7.31 \pm 0.06^{\mathrm{b}}$ \\
\hline \multicolumn{4}{c}{$\mathrm{a}, \mathrm{b}, \mathrm{c}, \mathrm{d}$ : For a given parameter, the values that do not share the same letter are significantly different. }
\end{tabular}

Protein digestibility is a nutritional parameter that evaluates the use of a protein s ource. This is influenced by several factors such as phenolic compounds, inhibitors of protein, and heat treatment [24]. Figure 1 shows the results obtained in this study for carob tree products.

There were significant differences $(p<0.05)$ in IVPD between the different samples tested. The highest digestibility value belongs to the carob pulp. It should also be highlighted that the seeds, which are the products of carob with the highest content in crude protein, showed the lowest digestibility value. 


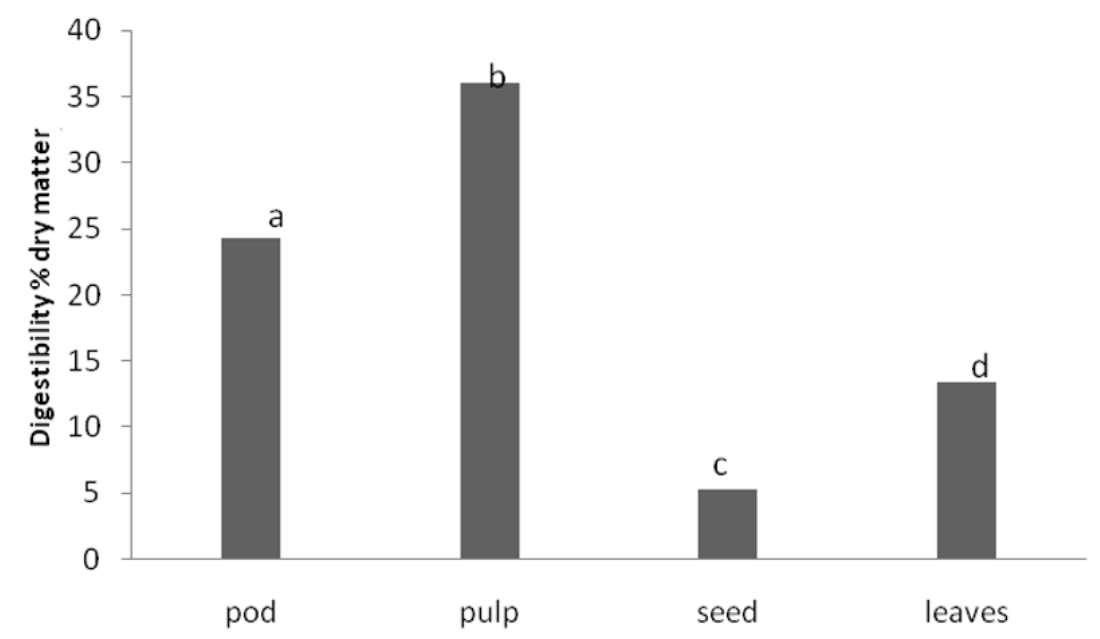

Figure 1. In vitro protein digestibility (IVPD) of carob tree products (percent dry matter). a, b, c, d: The values that do not share the same letter are significantly different.

\subsection{Secondary Metabolites Analysis}

The anti-nutritional composition of the carob products was analyzed in terms of trypsin inhibitory factor, which measure protease inhibitors. Protease inhibitors decrease the performance of these enzymes, having as a result lower protein digestibility. The other important factor is the phytic acid content, which has strong affinity for binding ions such as calcium and zinc, avoiding its absorption in the intestine and preventing various metabolic processes from being adversely affected. The values obtained for these anti-nutritional factors [18] in carob tree products are shown in Figures 2 and 3, respectively.

As can be observed in Figure 2, the trypsin inhibitory factor was lower in the pulp. The in vitro protein digestibility was also higher in the pulp. The phytic acid content was lower in the pulp than in the seeds and leaves. Leaving aside the leaves, the nutrient power of the carob tree is concentrated in the pulp. The seeds display the highest amount of the sum of anti-nutritional factors (proteins inhibitor and phytic acid).

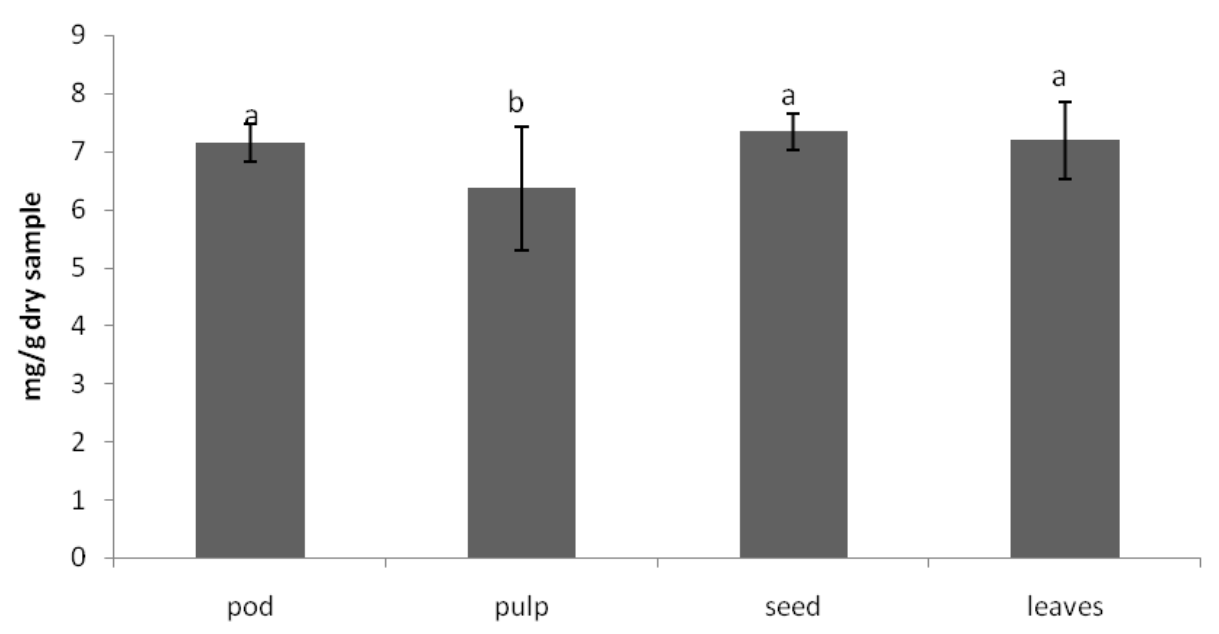

Figure 2. Trypsin inhibitory factor. a, b, c, d: The values that do not share the same letter are significantly different. 


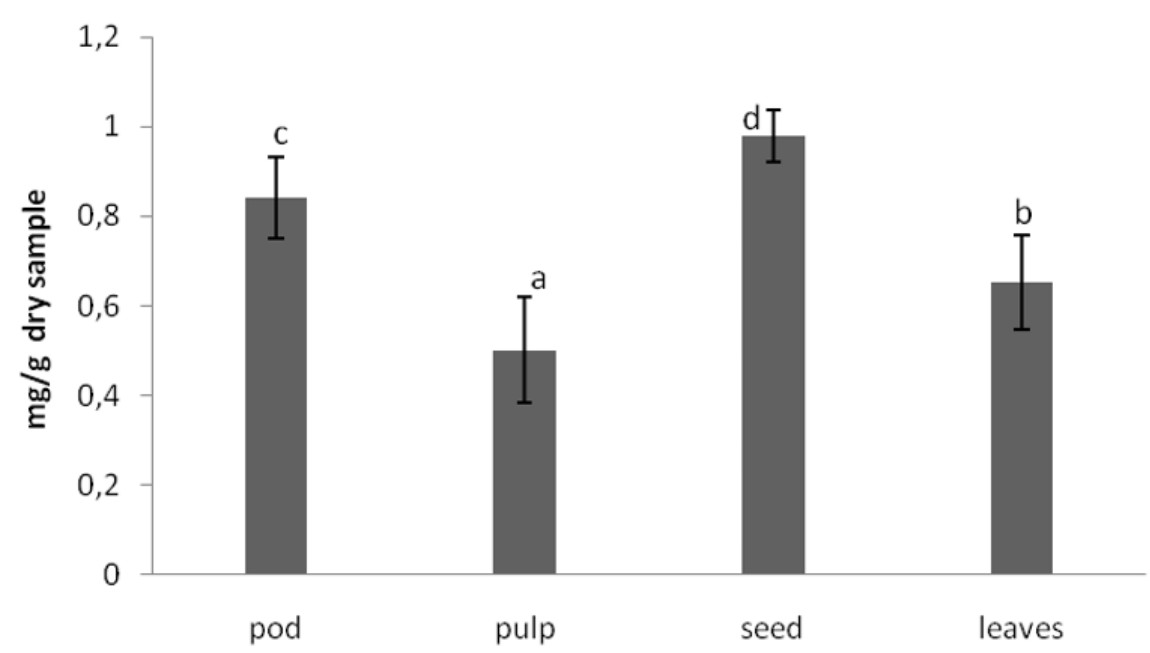

Figure 3. Phytic acid content of carob tree products. a, b, c, d: The values that do not share the same letter are significantly different

\subsection{Valorization Process}

Figure 4 shows an integral proposal for the full utilization of carob tree products. This approach includes proposed processes for the separation of the individual compounds analyzed before. As previously commented, the characterization of Algerian carob tree products shows a wide range of possibilities to valorize this natural material. For example, the carob pod contains low fat and high percentage of carbohydrates. These carbohydrates have many health benefits and could be used as human food product. Regarding the content of proteins, their digestibility must be taken into account to calculate the available amount of this type of nutrients. Since pods contain $4.0 \%$ protein with a digestibility rate of $24.8 \%$, the available amount of proteins is almost $1 \%$. For the case of the pulp, available proteins accounts for $1.05 \%$, and $0.93 \%$ for seeds and $0.88 \%$ for leaves. The highest amount of anti-nutrients such as trypsin inhibitor and phytic acid are present in the seed and leaves and thus the pulp offers the highest nutritional power among the carob tree products. Another interesting use of the anti-nutrient found in the seeds and leaves could be in medical applications, since it has been demonstrated that they exhibit a promising potential to prevent or treat cancer, circulatory diseases and infections. Phytic acid is well known as antioxidant that can form complexes with metals and prevent colon cancer [25]. It could also be used in the food industry, since the antioxidant $\left(\mathrm{Fe}^{3+}\right.$-chelating) properties of phytic acid make this compound a unique and versatile food preservative by, for example, inhibiting the oxidation of ascorbic acid stabilizes and by preventing the peroxidation and hydrolysis of fats and oils [26]. Finally, the high calorific values mainly of the pod and the pulp make possible their use as biomass for bioenergy production.

Focusing on carob pods, which would include a higher number of separation steps, they would need to be firstly subject to an aqueous extraction stage. The resulting sugar extract would then be filtered and afterward it would undergo demineralization and discoloration processes through ionic and/or cationic exchange resins. The product obtained would be then micro-filtered and concentrated, and the resulting syrup would go through the process of sugar inversion (conversion of sucrose into glucose plus fructose) by enzymes or cationic exchange resins. The non-sugar fraction (phytic acid and water-soluble polyphenols), pinitol and the discolored sugary extract (glucose and fructose) would be sequentially separated through an exchange column, preferably an ionic exchange column.

Phytic acid would remain in the non-sugar fraction resulting from the first separation step, and it could be separated in the last separation column by controlling the elution time or in an additional column of different composition.

The content of polyphenols in dry pulp is $18 \% w / w$. The fraction of water insoluble polyphenols could be separated by the hot extraction $\left(75-100^{\circ} \mathrm{C}\right)$ of the residue after the first extraction (see Figure 4 ). 
The resulting solution would then be cooled and the precipitate obtained would have approximately a content of $90 \% w / w$ in polyphenols. Water soluble polyphenols are separated from phytic acid in the last separation column. Alternative separation processes could be used for the separation of pinitol, such as extraction with organic solvents, ionic liquids or supercritical fluids to simplify the overall process.

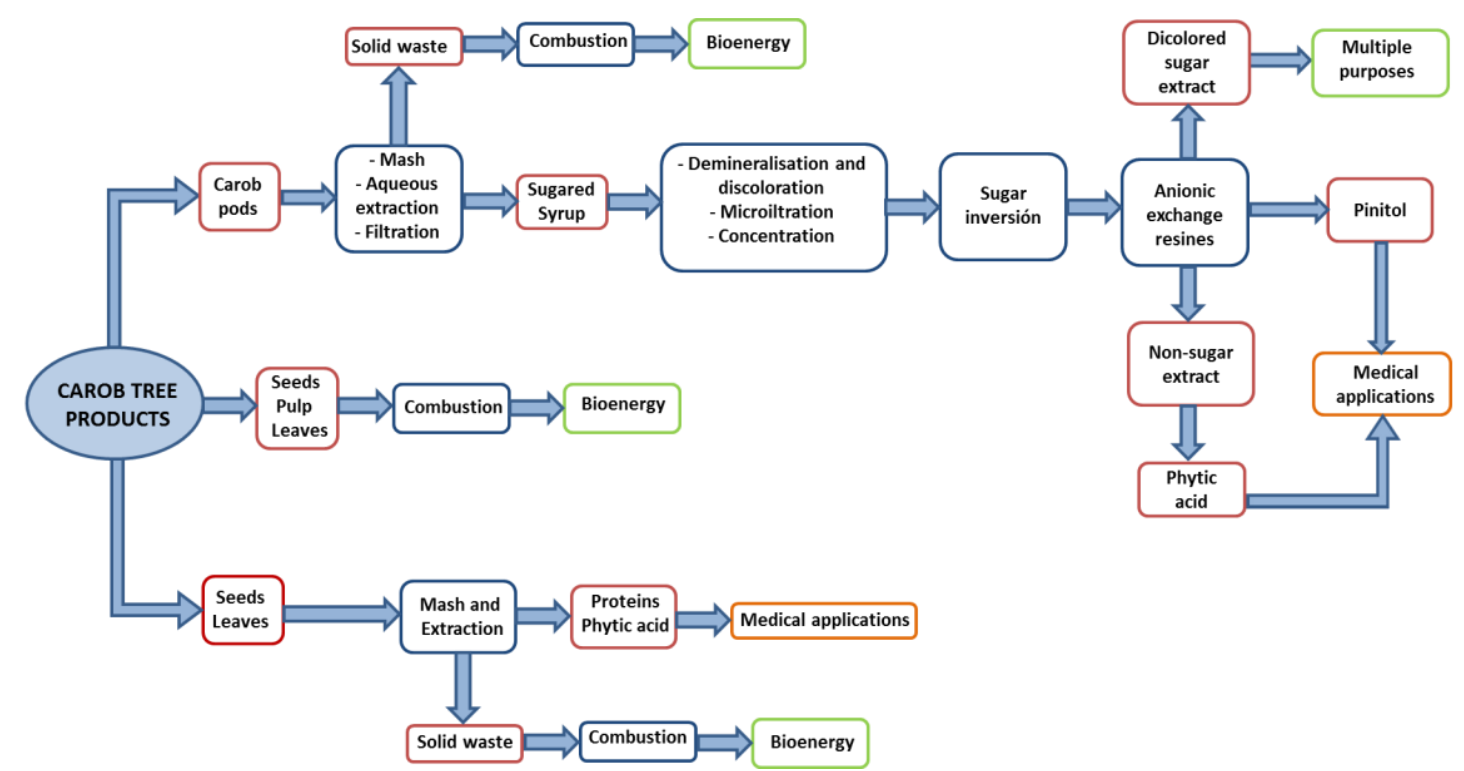

Figure 4. Integral approach for the valorization of Algerian carob tree products.

\section{Conclusions}

In this work, the nutrient and anti-nutrient contents of Algerian carob tree products (Ceratonia siliqua L.) (pod, pulp, seed and leaves) were analyzed. The pulp contains a high amount of carbohydrates, mainly sucrose. The protein and the phytic acid were mainly concentrated in the seeds and leaves. The low protein digestibility of the seeds and leaves is mainly due to its high content in anti-nutritional factors. Based on these results, the food application of carob pod involves the use of the pulp. The quantification of the secondary metabolites, namely trypsin inhibitory factor and phytic acid, has been reported for the first time in this study. The high content of these secondary metabolites in carob tree product could open new bio-medical applications since these compounds have been shown to have the potential for the treatment and prevention of cancer, infection and circulatory diseases. Finally, an integral approach was proposed for the full utilization of carob tree products.

Acknowledgments: This work was supported by the Spanish Ministry of Economy and Competitiveness by the FEDER (Fondo Europeo de Dearrollo Regional), ref ENE2014-54506-C2-2-R. Mahtout was supported by a mobility fellowship from the Faculty of Natural Sciences and Life, Abderrahmane Mira University, Bejaia (Algeria).

Author Contributions: Francisco José Hernández-Fernández, Antonia Pérez de los Ríos and Faidi Zaidi conceived, designed and supervised the experiments. Rosa Mahtout and Isabel Gracia perfomed the experiments and contributed to the preparation of the paper; María José Salar-García and Víctor Manuel Ortiz-Martínez contributed to the preparation of the paper and analyzed the data; Sergio Sanchez-Segado and Luis Javier Lozano-Blanco supervised the experiments and contributed to the preparation of the paper and data analysis.

Conflicts of Interest: The authors declare no conflict of interest.

\section{References}

1. Barracosa, P.; Osorio, J.; Cravador, A. Evaluation of fruit and seed diversity and characterization of carob (Ceratonia siliqua L.) cultivars in Algarve region. Sci. Hortic. 2007, 114, 250-257. [CrossRef] 
2. Vourdoubas, J.; Makris, P.; Kefalas, J.; Kaliakatsos, J. Studies on the production of bioethanol from carob. In Proceedings of the 12th National Conference and Technology Exhibition on Biomass for Energy, Industry and Climate Protection, Amsterdam, The Netherlands, 17-21 June 2002; pp. 489-493.

3. Geraldo, D.; Correia, P.J.; Filipe, J.; Nunes, L. Carob-tree as $\mathrm{CO}_{2}$ sink in the carbon market. In Advances in Climate Changes, Global Warming, Biological Problems and Natural Hazards; WSEAS Press: Faro, Portugal, 2010; pp. 119-123.

4. Mahmoud Sidina, M.; El Hansali, M.; Wahid, N.; Ouatmane, A.; Boulli, A.; Haddioui, A. Fruit and seed diversity of domesticated carob (Ceratonia siliqua L.) in Morocco. Sci. Hortic. 2009, 123, 110-116. [CrossRef]

5. Vourdoubas, J. Present and future uses of biomass for energy generation in the island of crete-Greece. J. Energy Power Sources 2015, 2, 158-163.

6. Sánchez, S.; Lozano, L.J.; Godínez, C.; Juan, D.; Pérez, A.; Hernández, F.J. Carob pod as a feedstock for the production of bioethanol in Mediterranean areas. Appl. Energy 2010, 87, 3417-3424. [CrossRef]

7. Vekiari, S.A.; Ouzounidou, G.; Ozturk, M.; Görk, G. Variation of quality characteristics in Greek and Turkish carob pods during fruit development. Soc. Behav. Sci. 2011, 19, 750-755. [CrossRef]

8. Karababa, E.; Coskuner, Y. Physical properties of carob bean (Ceratonia siliqua L.): An industrial gum yielding crop. Ind. Crop Prod. 2013, 42, 440-446. [CrossRef]

9. Roseiro, L.B.; Duarte, L.C.; Oliveira, D.L.; Roque, R.; Gabriela Bernardo-Gil, M.; Martins, A.I.; Sepúlveda, C.; Almeida, J.; Meireles, M.; Gírio, F.M.; et al. Supercritical, ultrasound and conventional extracts from carob (Ceratonia siliqua L.) biomass: Effect on the phenolic profile and antiproliferative activity. Ind. Crop Prod. 2013, 47, 132-138. [CrossRef]

10. Roukas, T. Citric acid production from carob pod by solid-state fermentation. Enzym. Microb. Technol. 1999, 24, 54-59. [CrossRef]

11. Vourdoubas, J. Efforts for the production of liquid biofuels in Crete: Bioethanol and biodiesel. In Comprehensive Economic and Spatial Bio-Energy Modelling; CIHEAM (Centre International de Hautes Études Agronomiques Méditerranéennes): Grignon, France, 2002; pp. 151-158.

12. Ercan, Y.; Irfan, T.; Mustafa, K. Optimization of ethanol production from carob pod extract using immobilized Saccharomyces cerevisiae cells in a stirred tank bioreactor. Bioresour. Technol. 2013, 135, 365-371. [CrossRef] [PubMed]

13. Mazaheri, D.; Shojaosadati, S.A.; Mousavi, S.M.; Hejazi, P.; Saharkhiz, S. Bioethanol production from carob pods by solid-state fermentation with Zymomonasmobilis. Appl. Energy 2012, 99, 372-378. [CrossRef]

14. Sánchez-Segado, S.; Lozano, L.J.; de los Ríos, A.P.; Hernández-Fernández, F.J.; Godínez, C.; Juan, D. Process design and economic analysis of a hypothetical bioethanol production plant using carob pod as feedstock. Bioresour. Technol. 2012, 104, 324-328. [CrossRef] [PubMed]

15. Fountoulakis, M.S.; Dokianakis, S.N.; Daskalakis, G.; Manios, T. Fermentative hydrogen production from carob pod: A typical mediterranean forest fruit. Waste Biomass Valorization 2014, 5, 799-805. [CrossRef]

16. Zilic, S.; Barac, M.; Pesic, M.; Dodig, D.; Ignjatovic-Micic, D. Characterization of proteins from grain of different bread and durum wheat genotypes. Int. J. Mol. Sci. 2011, 12, 5878-5894. [CrossRef] [PubMed]

17. Akeson, W.R.; Stahmann, M.A. A pepsin pancreatin digest index of protein quality. J. Nutr. 1964, 83, $257-261$. [PubMed]

18. Makkar, H.P.S.; Siddhuraju, P.; Becker. Trypsin Inhibitor. In Plant Secondary Metabolites; Springer: Berlin, Germany, 2007; pp. 1-29.

19. Biner, B.; Gubbuk, H.; Karhan, M.; Aksu, M.; Pekmezci, M. Sugar profiles of the pods of cultivated and wild types of carob bean (Ceratonia siliqua L.) in Turkey. Food Chem. 2007, 100, 1453-1455. [CrossRef]

20. Association of Official Analytical Chemists. Official Methods of Analysis of the Association of Official Analytical Chemists, 15th ed.; Helrich, K., Ed.; AOAC: Arlington, TX, USA, 1990; ISBN 0-935584-42-0.

21. Avallone, R.; Plessi, M.; Baraldi, M.; Monzani, A. Determination of chemical composition of carob (Ceratonia siliqua): Protein, fat, carbohydrates and tannins. J. Food Compos. Anal. 1997, 10, 166-172. [CrossRef]

22. Bhagya, B.; Sridhar, K.R.; Seena, S.; Bhat, R. Nutritional qualities of ripened beans of mangrove wild legume Canavalia cathartica Thouars. J. Agric. Technol. 2007, 3, 255-274.

23. Yousif, A.K.; Alghzawi, H.M. Processing and characterization of carob powder. Food Chem. 2000, 69, $283-287$. [CrossRef]

24. Antunes, P.L.; Bilhalva, A.B.; Elias, M.C.; Soares, G.J.D. Valor nutricional de feijão (Phaseolusvulgaris L.), cultivares rico 23, carioca, pirata-1 e rosinha-G2. Rev. Bras. Agrociênc. 1995, 1, 12-18. 
25. Graf, E.; Eaton, J.W. Antioxidant function of phytic acid. Free Radic. Biol. Med. 1990, 8, 61-69. [CrossRef]

26. Oatway, L.; Vasanthan, T.; Helm, J.H. Phytic acid. Food Rev. Int. 2001, 17, 419-431. [CrossRef] (CC BY) license (http:/ / creativecommons.org/licenses/by/4.0/). 